\title{
HYPERCHOLESTEROLEMIAS: PATHOGENESIS AND PATHOPHYSIOLOGICAL IMPLICATIONS
}

\section{HIPERHOLESTEROLEMIJE: MEHANIZMI NASTANKA I PATOFIZIOLOSKE IMPLIKACIJE}

\author{
Danijela Vučević', Drago Đorđević, Marija Stanojević', Bojan Jorgačević', Danka Đorović,' Đorđe Radak², Tatjana Radosavljevićl
}

\section{Summary}

In this review, we provide an overview of recent literature data and practical knowledge related to hypercholesterolemias and their pathophysiological implications. Elevated blood lipid levels (hyperlipidaemias) are the most common metabolic disorders in global population. There is consensus regarding hypercholesterolemia, hypertension and cigarette smoking as the three main risk factors for atherothrombosis, with consequences such as cardiovascular and cerebrovascular diseases, being the leading cause of morbidity and mortality worldwide. In relation to this, familial hypercholesterolemia is the most deleterious precursor of coronary artery disease. This severest form of hyperlipidaemia refers to an inherited disorder of cholesterol metabolism due to defects in the receptor for low density lipoprotein (LDL). Besides, numerous factors, including drugs, can influence lipid status and significantly contribute to the development of secondary hypelipidaemias. Thus, inappropriate diet, obesity, diabetes mellitus and alcohol use, in particular, are commonly associated with high blood lipid levels. Therefore, secondary causes of high blood lipids should be considered in each patient with a lipid disorder before lipid-lowering therapy is started. Having in mind the increase of prevalence of lipid metabolism disorders in future, it is necessary to take preventive actions to decrease risk factors (inappropriate diet rich in carbohydrates and saturated fat, obesity, cigarette smoking, sedentary lifestyle and physical inactivity). However, although various studies related to this medical problem have been carried out, scientists are still far from a complete understanding of the molecular basis of this problem.

Key words: primary hyperlipidaemias, secondary disorders of lipid metabolism

\section{Sažetak}

U okviru ovog preglednog članka dat je prikaz najnovijih literaturnih podataka i praktičnih saznanja o hiperholesterolemijama i njihovim patofiziološkim implikacijama. Povišene vrednosti lipida u krvi (hiperlipidemije) su najčešći metabolički poremećaji u opštoj populaciji. Postoji konsenzus da su hiperholesterolemija, hipertenzija i pušenje duvana tri glavna faktora rizika za nastanak i razvoj aterotromboze, čije se posledice manifestuju u vidu kardiovaskularnih i cerebrovaskularnih bolesti i predstavljaju vodeće uzroke morbiditeta i mortaliteta širom sveta. S tim u vezi, familijarna hiperholesterolemija je najopasniji prekursor koronarne bolesti. Ovaj najteži oblik hiperlipidemije nastaje usled naslednog poremećaja funkcije receptora za lipoproteine male gustine (LDL). 0sim toga, brojni faktori, uključujući tu i lekove, mogu da utiču na lipidni status i značajno doprinesu razvoju sekundarnih hiperlipidemija. Tako su nepravilna ishrana, gojaznost, dijabetes melitus i konzumiranje alkohola naročito povezani sa povišenim vrednostima lipida u krvi. Stoga, kod svakog pacijenta sa poremećajem metabolizma lipida treba razmotriti sekundarne uzroke hiperlipidemija pre uvođenja medikamentne terapije. Imajući u vidu tendenciju sve većeg porasta prevalencije poremećaja metabolizma lipida u budućnosti, neophodno je preduzimanje preventivnih mera za suzbijanje faktora rizika na koje se može uticati (neodgovarajuća ishrana bogata ugljenim hidratima i zasićenim masnim kiselinama, gojaznost, pušenje duvana, sedentarni način života i fizička neaktivnost). Međutim, uprkos raznim istraživanjima ovog medicinskog problema, naučnici su još uvek daleko od potpunog razumevanja njegove molekulske osnove.

Ključne reči: primarne hiperlipidemije, sekundarni poremećaji metabolizma lipida

UvoD

Istražite sve što vas okružuje, prodrite do najdaljih granica ljudskog znanja, i na kraju ćete uvek doći do nečega neobjašnjivog. To je ono što se zove život. dr Albert Švajcer

Holesterol je najrasprostranjeniji lipid u organizmu (1). Prisutan je u slobodnom (neesterifikovanom) obliku i esterifikovanoj formi $(1,2)$. U čistom obliku, holesterol je beličasta mekana voštana supstanca, nerastvorljiva u vodi (3). Ovaj najbolje proučen lipid od svih lipidnih komponenti u organizmu, predstavlja neizostavni gradivni deo svake ćelije. Pored toga, holesterol je i polazna materija za sintezu hormona nadbubrežnih i polnih žlezda, kao i vitamina D i žučnih kiselina (3). U plazmi je oko $75 \%$ holesterola u esterifikovanom obliku, najčešće sa polinezasićenom linolnom masnom kiselinom (1).
Slobodni holesterol se nalazi najvećim delom u tkivima (2). Oko $2 / 3$ holesterola se sintetiše u organizmu (približno $900 \mathrm{mg}$ dnevno), a ostatak se unosi hranom (1). Očuvan metabolizam holesterola je od vitalnog značaja za normalno funkcionisanje svake ćelije. Međutim, njegovi štetni efekti se ispoljavaju ukoliko je u krvi prisutan u znatno višoj koncentraciji od normalne (3).

Postoji konsenzus da su hiperholesterolemija, hipertenzija i pušenje duvana tri glavna faktora rizika za nastanak i razvoj aterotromboze, čije se posledice manifestuju 
u vidu kardiovaskularnih (KVS) i cerebrovaskularnih (CVS) bolesti i predstavljaju vodeće uzroke morbiditeta i mortaliteta savremenog čoveka (4-11). U svetu više od 17 miliona ljudi godišnje izgubi život zbog bolesti srca i krvnih sudova (9). S tim u vezi, epidemiološke studije su pokazale da je smrtnost od ishemijske bolesti srca (ISB) naročito visoka u zemljama $\mathrm{u}$ tranziciji, sa tendencijom daljeg porasta za $137 \%$ kod muškaraca i $120 \%$ kod žena (4). Takođe, u našoj zemlji, prema podacima Instituta za javno zdravlje Srbije „Dr Milan Jovanović Batut“ vodeći uzrok smrti je ISB (4). Štaviše, svakoga dana 47 ljudi u našoj zemlji doživi infarkt miokarda, a 15 ga ne preživi (8).

Povišene vrednosti lipida u krvi (hiperlipidemije) su najčešći metabolički poremećaji u opštoj populaciji (12). Prema podacima NHLBI (engl. National Heart, Lung and Blood Institute), u Sjedinjenim Američkim Državama (SAD) približno $36 \%$ odraslih ljudi i $10 \%$ dece starosti između 9 i 12 godina imaju povišene vrednosti holesterola (4). Rizik od ISB se povećava za $2-3 \%$ za svako sukcesivno povećanje nivoa ukupnog holesterola (UH) po $1 \%$, tako da muškarci stari između 55 i 65 godina, kod kojih je UH povišen za $10 \%$, imaju povećan mortalitet od ISB za $38 \%$ (9). Pored toga, pokazano je da muškarci $\mathrm{s} U \mathrm{UH}$ većim od $8 \mathrm{mmol} / \mathrm{L}$ i žene kod kojih je vrednost ove lipidne frakcije veća od $6 \mathrm{mmol} / \mathrm{L}$ imaju od tri do pet puta veći rizik da obole od ISB u toku narednih pet godina života (4). Ustanovljeno je, takođe, da se samo snižavanjem vrednosti lipoproteina male gustine (LDL holesterola, engl. low density lipoprotein) može smanjiti morbiditet i mortalitet od ISB za približno 40\% (13).
Na koncentraciju holesterola u krvi utiče povećan unos samog holesterola, nekih zasićenih masnih kiselina dugog lanca i trans izomera nezasićenih masnih kiselina (3). Prekomeran energetski unos takođe utiče na koncentraciju holesterola u krvi $(3,4)$.

Prosečan dnevni unos holesterola u mnogim zemljama, posebno u razvijenom svetu, iznosi 450-500 mg (3). Posebno bogati izvori holesterola su žumance jajeta (jedno žumance kokošjeg jajeta sadrži oko 280 mg holesterola), sve iznutrice (najviše mozak, a zatim jetra /crna džigerica/, bubrezi i srce), riblja ikra, kavijar, buter, punomasno mleko i njegovi proizvodi (sir, kajmak, pavlaka, sladoled, i slično), majonez, masna mesa, masne mesne prerađevine i životinjska mast (3). Kada je ovaj lipid u pitanju, dokazano je da fiziološke dnevne potrebe odrasle osobe iznose 150-300 mg (14). Prema preporukama koje je dalo Američko udruženje za borbu protiv bolesti srca i krvnih sudova (AHA, engl. American Heart Association), u prvom stepenu dijete koji se odnosi na lakše slučajeve poremećaja metabolizma lipida, dnevni unos holesterola se ograničava ispod $300 \mathrm{mg}$, a u drugom stepenu (teži oblici izmenjenog metabolizma lipida) ispod $200 \mathrm{mg}$ (9). Dokazano je da na svakih $100 \mathrm{mg}$ povećanja holesterola u ishrani dnevno, koncentracija holesterola u krvi raste za 0.21-0.26 mmol/L (3).

\section{HiPERLIPIDEMIJE}

Pojam hiperlipidemija, poznat i kao hiperlipoproteinemija ili dislipidemija (dislipoproteinemija), označava

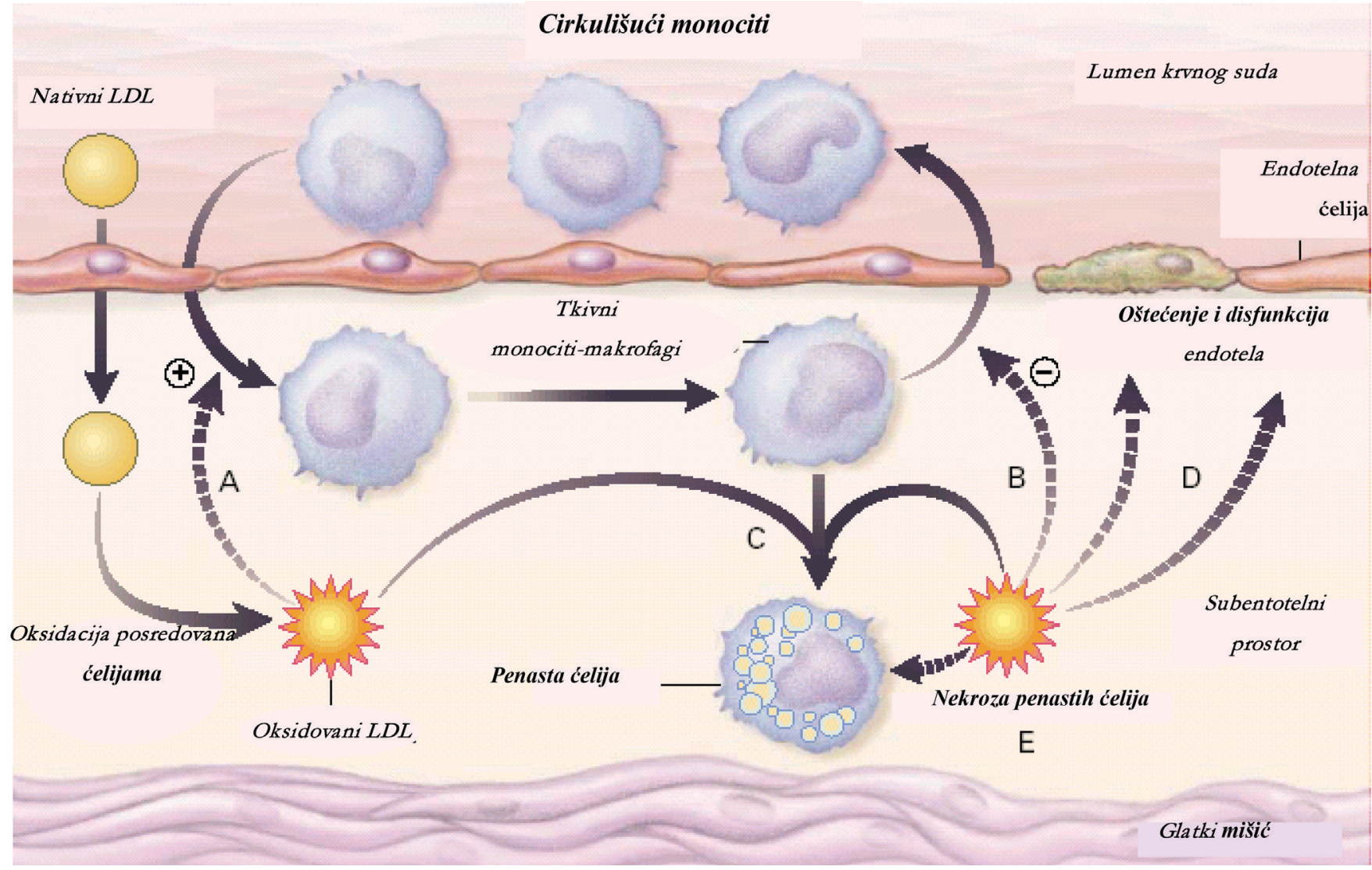

Slika 1. Rani događaji u aterogenezi (17; modifikivano) 
Tabela 1. Fredriksonova klasifikacija hiperlipoproteinemija

$\begin{array}{lllllll}\text { Fenotip } & \mathrm{UH} & \mathrm{HDL} & \mathrm{TG} & \text { Lipoprotein } & \text { Aterogenost } & \text { Učestalost } \\ \text { tip I } & \mathrm{N} / \uparrow & \downarrow & \uparrow \uparrow \uparrow & \text { HM } & \text { neznatna } & \text { ispod } 1 \% \\ \text { tip IIa } & \uparrow \uparrow & \mathrm{N} / \downarrow & \mathrm{N} & \mathrm{LDL} & +++ & 10-15 \% \\ \text { tip IIb } & \uparrow \uparrow & \downarrow / \mathrm{N} & \uparrow & \text { LDL, VLDL } & +++ & 25-40 \% \\ \text { tip III } & \uparrow \uparrow & \downarrow & \uparrow & \text { IDL } & +++ & \text { ispod } 1 \% \\ \text { tip IV } & \mathrm{N} / \uparrow & \downarrow & \uparrow \uparrow & \text { VLDL } & +++ & 45-60 \% \\ \text { tip V } & \uparrow & \downarrow & \uparrow \uparrow \uparrow & \text { VLDL, HM } & + & \text { do } 5 \%\end{array}$

UH - ukupni holesterol; TG - trigliceridi; HM - hilomikroni;

HDL- lipoproteini velike gustine (engl. high density lipoproteins);

VLDL- lipoproteini vrlo male gustine (engl. very low density lipoproteins);

LDL- lipoproteini male gustine (engl. low density lipoproteins);

IDL- lipoproteini intermedijarne gustine (engl. intermediate density lipoproteins)

N-normalan; $\uparrow$ - povišen; $\downarrow$ - snižen; + - stepen aterogenosti

poremećaje metabolizma koji dovode do povećanja jedne ili više frakcija lipida i lipoproteina u krvi $(4,15,16)$. Uopšteno govoreći, hiperlipidemije mogu imati različite posledice, pri čemu je najznačajnija ubrzana i/ili prevremena aterogeneza (Slika 1) (17).

One mogu biti primarne (nasledne) ili sekundarne (javljaju se kao posledica osnovne bolesti ili su posledica uzimanja lekova) $(4,15,16)$. Uz to, hiperlipidemije se mogu podeliti prema vrsti lipida koji su povišeni u krvi (hiperlipoproteinemija, hiperholesterolemija i hipertrigliceridemija) $(4,16)$, patogenetskim uzrocima nastan$\mathrm{ka}$, kao i prema tome koja je lipidna frakcija dominantno povišena (4). Neophodno je istaći da je za procenu neželjenih efekata pojedinih hiperlipidemija važna vrednost ukupnog sadržaja holesterola i triglicerida (TG), pri čemu posebno mesto zauzima određivanje vrednosti LDL i HDL holesterola (HDL, engl. high density lipoprotein), non HDL holesterola, kao i njihovih međusobnih odnosa $(4,15)$. Takođe su važne i promene u strukturi i veličini lipoproteinskih čestica, jer to određuje njihovu ulogu, metabolizam i patofiziološki značaj $(4,14,18)$.
Kod normolipidemijskih dislipidemija poremećeni su odnosi između pojedinih lipidnih frakcija na način koji ne dovodi do bitnijeg povećanja osnovnih lipidnih frakcija (4). Međutim, normolipidemijske dislipidemije takođe imaju uticaj na aterogenezu (Slika 1) $(3,4)$.

Za postavljanje dijagnoze hiperlipidemije važno je kada i kako se uzimaju uzorci krvi, kao i koje se lipidne frakcije određuju $(3,4)$. Pored toga, potrebna je detaljna analiza porodične anamneze, ispitivanje postojanja drugih bolesti koje bi mogle da utiču na nivo lipida, kao i analiza terapije koju je pacijent koristio, zbog mogućeg uticaja nekih lekova na lipidni status (4).

\section{Primarne hiperlipidemije}

Primarne hiperlipidemije nastaju zbog genetskih poremećaja u metabolizmu pojedinih lipoproteinskih česti$\mathrm{ca}$, usled izmenjene funkcije odgovarajućih receptora, neadekvatnog sadržaja i funkcije apoproteina ili narušene aktivnosti enzima koji učestvuju u metabolizmu li-

Tabela 2. Etiopatogenetska klasifikacija primarnih hiperlipidemija

\begin{tabular}{ll} 
Primarna hiperlipidemija & Fenotip $^{*}$ \\
$\begin{array}{l}\text { Izolovane hiperholesterolemije } \\
\text { Familijarna hiperholesterolemija } \\
\text { - homozigotna }\end{array}$ & fenotip IIa \\
- heterozigotna & \\
$\begin{array}{l}\text { Familijarni deficit apolipoprotein B-100 } \\
\text { Poligenska hiperholesterolemija }\end{array}$ & fenotip IIa \\
$\begin{array}{l}\text { Izolovane hipertrigliceridemije } \\
\text { Familijarna hipertrigliceridemija }\end{array}$ & fenotip Iia \\
$\begin{array}{l}\text { Familijarni deficit lipoproteinske lipaze } \\
\text { Familijarni deficit apolipoproteina C-II }\end{array}$ & fenotip IV \\
$\begin{array}{l}\text { Hiperholesterolemije udružene sa hipertrigliceridemijom } \\
\text { Familijarna kombinovana hiperlipidemija } \\
\text { Disbetalipoproteinemija }\end{array}$ & fenotip I, V \\
$\begin{array}{l}\text { Familijarna hiperalfalipoproteinemija } \\
\text { (sindrom dugog života) }\end{array}$ & \\
\hline
\end{tabular}

* - fenotip je naveden prema Fredriksonovoj klasifikaciji hiperlipidemija

\# - HDL holesterol je 2-3 puta povećan u odnosu na njegove normalne vrednosti, dok je sadržaj LDL normalan. Javlja se kod 1\% opšte populacije, koja je zbog antiaterogenog sklopa lipidnog profila zaštićena od pojave KVS 
Tabela 3. Podela primarnih hiperlipidemija prema dominantnom tipu poremećaja

\begin{tabular}{|c|c|c|c|}
\hline \multicolumn{2}{|c|}{ Dominantna hiperholesterolemija } & \multicolumn{2}{|c|}{ Dominantna hipertrigliceridemija } \\
\hline \multicolumn{2}{|c|}{ Familijarna hiperholesterolemija } & \multicolumn{2}{|l|}{ Familijarna hipertrigliceridemija } \\
\hline \multicolumn{2}{|c|}{ Familijarni deficit apolipoprotein B-100 } & \multicolumn{2}{|c|}{ Familijarni deficit lipoproteinske lipaze } \\
\hline \multicolumn{2}{|c|}{ Poligenska hiperholesterolemija } & \multicolumn{2}{|c|}{ Familijarni deficit apolipoproteina C-II } \\
\hline $\operatorname{Tip}^{*}$ & Uobičajen naziv & Promene lipoproteina & Genetski poremećaj \\
\hline I & $\begin{array}{l}\text { Spoljna dijetna hiperlipidemija; } \\
\text { Mastima izazvana hiperTG }\end{array}$ & Povećanje TG (trostruko) i HM & Mutacija gena LPL \\
\hline IIa & Familijarna hiperholesterolemija & Povećanje holesterola iz LDL & $\begin{array}{l}\text { Mutacija gena receptora LDL ili gena } \\
\text { APOB }\end{array}$ \\
\hline IIb & $\begin{array}{l}\text { Kombinovana hiperlipidemija; } \\
\text { HiperTG izazvana ugljenim hidratima }\end{array}$ & Povećanje LDL, VLDL i TG & $\begin{array}{l}\text { Poligenski, višestruko poreklo; mu- } \\
\text { tacija gena LPL ili gena APOB }\end{array}$ \\
\hline III & $\begin{array}{l}\text { Disbetalipoproteinemija: } \\
\text { Hiperlipidemija (HM) ostataka }\end{array}$ & $\begin{array}{l}\text { Povećanje HM ostataka, TG, } \\
\text { IDL i holesterola }\end{array}$ & Mutacija gena APOE \\
\hline IV & $\begin{array}{l}\text { Endogena hiperlipidemija; HiperTG izazvana uglje- } \\
\text { nim hidratima i dr. }\end{array}$ & Povećanje VLDL i TG & Nepoznat; poligenski \\
\hline $\mathrm{V}$ & $\begin{array}{l}\text { Mešovita hiperlipidemija; HiperTG izazvana uglje- } \\
\text { nim hidratima i mastima }\end{array}$ & $\begin{array}{l}\text { Povećanje TG, VLDL, HM, LDL } \\
\text { i holesterola }\end{array}$ & $\begin{array}{l}\text { Poligenski; mutacije gena APOC2, } \\
\text { LPL i APOA5 kod nekih obolelih } \\
\text { osoba }\end{array}$ \\
\hline
\end{tabular}

* - tip je naveden prema Fredriksonovoj klasifikaciji hiperlipidemija; TG- trigliceridi; HM- hilomikroni; LDL- lipoproteini male gustine (engl. low density lipoproteins); VLDL- lipoproteini vrlo male gustine (engl. very low density lipoproteins); IDL- lipoproteini intermedijarne gustine (engl. intermediate density lipoproteins); LPL- lipoproteinska lipaza

Tabela 5. Genetski poremećaji nekih primarnih hiperlipidemija

\begin{tabular}{ll} 
Primarna hiperlipidemija & Genski nedostatak i nasleđivanje \\
\hline Nedostatak lipoproteinske lipaze (LPL) & LpL (LPL) - 8p22; autozomno recesivno (AR); porodično \\
\hline Familijarni deficit apolipoproteina C-II & Apolipoprotein C-II (ApoC-II /APOC2/) - 19q13.2; AR \\
Familijarni deficit hepatičke lipaze & Hepatička lipaza (LIPC) - 15q21-q23; AR \\
\hline Familijarna disbetalipoproteinemija & ApoE (APOE) 19q13.2; AR, autozomno dominantno (AD) \\
Familijarna hiperholesterolemija & LDL receptor (LDLR) - 19p13.3; AD \\
Familijarni deficit apo B-100 & Apolipoprotein B-100 (ApoB-100/APOB/) - 2p24-p23; AD \\
\hline AR hiperholesterolemija & ARH (ARH) - 1p36-p35; AR
\end{tabular}

pida, kao i kombinovanjem više navedenih poremećaja $(4,16)$. U većini slučajeva karakterišu se ranom i izraženom aterosklerozom (Slika 1) (4). U kliničkoj praksi primarne i sekundarne hiperlipidemije se najčešće klasifikuju prema podeli koju je dao američki naučnik Fredrikson (Fredrickson) 1967. godine i koju je nekoliko godina kasnije dopunio ekspertski tim Svetske zdravstvene organizacije (SZO) (Tabela 1) $(3,4)$.

Imajući u vidu da se danas dosta zna o etiopatogenezi poremećaja metabolizma lipida, prednost se daje modernoj klasifikaciji primarnih hiperlipidemija, koja vodi računa o njihovim uzrocima i mehanizmima nastanka i razvoja (Tabela 2) (3). Uz to, danas se češće koristi i podela primarnih hiperlipidemija na osnovu dominantnog tipa ispoljavanja lipidnog poremećaja (Tabela 3) (4).

Primarni poremećaji lipoproteina su podeljeni u nekoliko tipova (Tabela 4), dok su na narednoj tabeli prikazani nasledni poremećaji nekih primarnih hiperlipidemija (Tabela 5) (16).
Genetski nedostaci mogu uzrokovati nakupljanje odredene klase lipoproteinskih čestica $(3,16)$. Mutacije u genima za ključne proteine (uključujući apoproteine, enzime i receptore) u metabolizmu lipoproteina uzrokuju tip I (hilomikronemija), tip II (povećanje LDL), tip III (povećanje IDL) i druge hiperlipoproteinemije (Tabela 4) (16). Jedan deo obolelih osoba sa primarnom hiperlipidemijom ima nedostatke čiji molekulski poremećaj nije sasvim određen, uglavnom zbog poligenskih činilaca i egzogenih faktora koji doprinose hiperlipidemiji $(16,19)$.

Osnovne karakteristike najčešćih oblika primarnih hiperlipidemija (izolovanih hiperholesterolemija, izolovanih hipertrigliceridemija i hiperholesterolemija udruženih sa hipertrigliceridemijom) navedene su na Tabelama 6-8 i Slikama 2 i $3(4,16)$.

Mutacije gena ključnih proteina u stvaranju i razgradnji HDL dovode do znatnih promena količine HDL holesterola $(16,18)$. Genetski nedostaci primarnih poremećaja metabolizma HDL i njihova ispoljavanja prikazani su 
Tabela 6. Osnovne karakteristike izolovanih hiperholesterolemija

\begin{tabular}{|c|c|c|c|}
\hline $\begin{array}{l}\text { Familijarna homozigotna } \\
\text { hiperholesterolemija }\end{array}$ & $\begin{array}{l}\text { UH u plazmi je iznad } 13 \mathrm{mmol} / \mathrm{L} \\
\text { (UH u plazmi je iznad } 500 \mathrm{mg} / \mathrm{dL} \text { ) }\end{array}$ & $\uparrow \mathrm{LDL}$ & $\begin{array}{l}\text { Tetivni ksantomi* i KVS u de- } \\
\text { tinjstvu\# }\end{array}$ \\
\hline $\begin{array}{l}\text { Familijarna heterozigotna } \\
\text { hiperholesterolemija }\end{array}$ & $\begin{array}{l}\text { UH u plazmi je } 7-13 \mathrm{mmol} / \mathrm{L} \\
\text { (UH u plazmi je } 275-500 \mathrm{mg} / \mathrm{dL} \text { ) }\end{array}$ & $\uparrow \mathrm{LDL}$ & $\begin{array}{l}\text { Tetivni ksantomi* i KVS u odra- } \\
\text { slih osoba\# }\end{array}$ \\
\hline $\begin{array}{l}\text { Familijarni deficit apolipoprotein } \\
\text { B-100 }\end{array}$ & $\begin{array}{l}\text { UH u plazmi kod heterozigota je } \\
7-13 \mathrm{mmol} / \mathrm{L}(275-500 \mathrm{mg} / \mathrm{dL})\end{array}$ & $\uparrow \mathrm{LDL}$ & Tetivni ksantomi* i KVS \\
\hline Poligenska hiperholesterolemija & $\begin{array}{l}\text { UH u plazmi je } 6.5-9.0 \mathrm{mmol} / \mathrm{L} \\
\text { (UH u plazmi je } 250-350 \mathrm{mg} / \mathrm{dL} \text { ) }\end{array}$ & $\uparrow \mathrm{LDL}$ & $\begin{array}{l}\text { Nema ksantoma; postoji rizik za } \\
\text { KVS }\end{array}$ \\
\hline
\end{tabular}

UH- ukupni holesterol; LDL- lipoproteini male gustine (engl. low density lipoproteins);

$\uparrow$ - povišen; KVS- kardiovaskularne bolesti; \# - Slika 2; *- Slika 3a

Tabela 7. 0snovne karakteristike izolovanih hipertrigliceridemija

\begin{tabular}{|c|c|c|c|}
\hline $\begin{array}{l}\text { Familijarna } \\
\text { hipertrigliceridemija }\end{array}$ & $\begin{array}{l}\text { TG u plazmi je } 2.8-8.5 \mathrm{mmol} / \mathrm{L}(250-750 \mathrm{mg} / \\
\mathrm{dL}) \text {; plazma može biti zamućena }\end{array}$ & $\uparrow \mathrm{VLDL}$ & $\begin{array}{l}\text { Asimptomatska; može biti } \\
\text { udružena sa } \uparrow \text { rizikom za KVS }\end{array}$ \\
\hline $\begin{array}{l}\text { Familijarni deficit } \\
\text { lipoproteinske lipaze }\end{array}$ & $\begin{array}{l}\text { TG u plazmi je iznad } 8.5 \mathrm{mmol} / \mathrm{L} \\
\text { (iznad } 750 \mathrm{mg} / \mathrm{dL} \text { ); plazma može biti mlečna }\end{array}$ & $\uparrow \mathrm{HM}$ & $\begin{array}{l}\text { Erupcijski ksantomi; hepato- } \\
\text { splenomegalija; } \\
\text { pankreatitis; bol u abdomenu }\end{array}$ \\
\hline $\begin{array}{l}\text { Familijarni deficit apolipoprotein } \\
\text { C-II }\end{array}$ & $\begin{array}{l}\text { TG u plazmi je iznad } 8.5 \mathrm{mmol} / \mathrm{L} \\
\text { (iznad } 750 \mathrm{mg} / \mathrm{dL} \text { ); plazma može biti mlečna }\end{array}$ & $\uparrow \mathrm{HM}$ & $\begin{array}{l}\text { Erupcijski ksantomi*; hepato- } \\
\text { splenomegalija; } \\
\text { pankreatitis }\end{array}$ \\
\hline
\end{tabular}

TG- trigliceridi; VLDL- lipoproteini vrlo male gustine (engl. very low density lipoproteins);

HM- hilomikroni; $\uparrow$ - povišen; KVS- kardiovaskularne bolesti; ${ }^{*}$ Slika 3b

Tabela 8. Osnovne karakteristike hiperholesterolemija udruženih sa hipertrigliceridemijom

\begin{tabular}{|c|c|c|c|}
\hline $\begin{array}{l}\text { Kombinovana } \\
\text { hiperlipidemija }\end{array}$ & $\begin{array}{l}\text { TG u plazmi je } 2.8-8.5 \mathrm{mmol} / \mathrm{L}(250-750 \mathrm{mg} / \mathrm{dL}) \text {; } \\
\text { UH u plazmi je } 6.5-13 \mathrm{mmol} / \mathrm{L}(250-500 \mathrm{mg} / \mathrm{dL})\end{array}$ & $\uparrow \mathrm{LDL}$ i VLDL & $\begin{array}{l}\text { Asimptomatska do pojave KVS; fami- } \\
\text { lijarni oblik može imati ili samo TG ili } \\
\text { samo LDL }\end{array}$ \\
\hline Disbetalipoproteinemija & $\begin{array}{l}\text { TG u plazmi je } 2.8-8.5 \mathrm{mmol} / \mathrm{L}(250-750 \mathrm{mg} / \mathrm{dL}) \\
\text { UH u plazmi je } 6.5-13 \mathrm{mmol} / \mathrm{L}(250-500 \mathrm{mg} / \mathrm{dL})\end{array}$ & $\begin{array}{l}\uparrow \text { VLDL i IDL; } \\
\text { N LDL }\end{array}$ & $\begin{array}{l}\text { Asimptomatska do pojave KVS; pal- } \\
\text { marni ili tuberoerupcijski ksantomi* }\end{array}$ \\
\hline
\end{tabular}

TG- trigliceridi; VLDL- lipoproteini vrlo male gustine (engl. very low density lipoproteins);

LDL- lipoproteini male gustine (engl. low density lipoproteins); IDL-lipoproteini intermedijarne gustine (engl. intermediate density lipoproteins); UH-ukupni holesterol; N-normalan; $\uparrow$ - povišen;

KVS - kardiovaskularne bolesti; *- Slika 3b i Slika 3c

na Tabeli 9, dok su najznačajnije karakteristike ostalih primarnih hiperlipidemija naznačene na Tabeli 10 (16).

Familijarna hiperholesterolemija.- Familijarna hiperholesterolemija (FH) je monogenski poremećaj metabolizma koji zbog posledica do kojih dovodi na krvnim

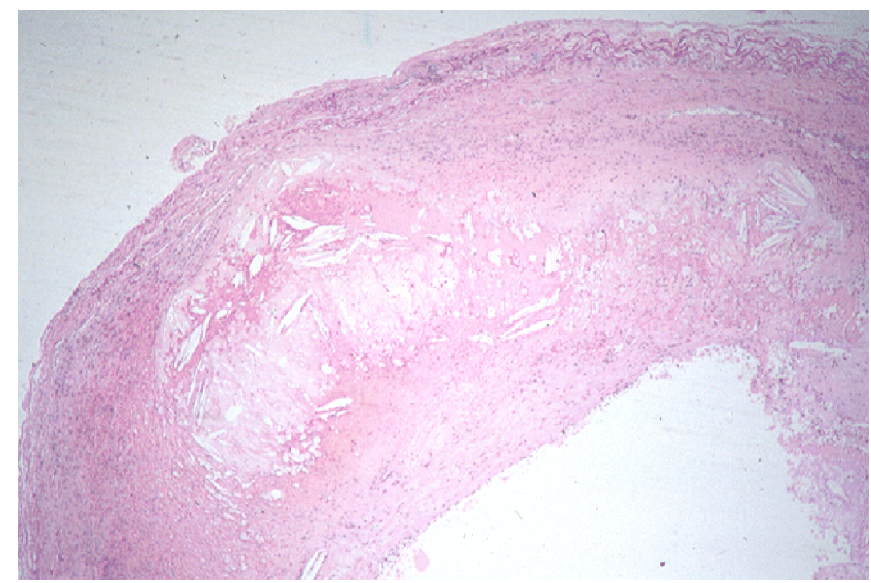

Slika 2. Brojni beli igličasti kristali holesterola u arterijskom zidu pacijenta sa familijarnom hiperholesterolemijom

Izvor: http://www.answers.com/topic/familial-hypercholesterolemia\#ixzz1qVWUo6tu -0 porodičnoj hiperholesterolemiji sudovima (prvenstveno na koronarnim arterijama), predstavlja najteži oblik hiperlipidemije $(3,19)$. Smatra se da je rizik koronarne bolesti u obolelih od FH čak 25 puta veći u poređenju sa zdravim osobama iste životne dobi (3). FH je značajna i kao posebna ilustracija dinamične povezanosti medicine i genetike, koja je osvetlila glavne mehanizme nastanka ateroskleroze (20). Naime, u seriji eksperimenata koji predstavljaju temelj moderne patofiziologije i medicinske genetike, američki naučnici Majkl Braun (Michael Brown) i Džozef Goldštajn (Josef Goldstein) (Slika 4) su utvrdili da se u osnovi FH nalazi urođeni poremećaj funkcije receptora za LDL (Slika 5). Za taj svoj epohalni pronalazak, ovi naučnici su 1985. godine dobili Nobelovu nagradu za fiziologiju i medicinu (3).

Gen za LDL receptor se nalazi na 19. hromozomu, zauzima 45 kilo baza (kb /hiljadu baznih parova/) i sastoji se iz 18 kodirajućih regiona, egzona $(19,20)$. Ovaj gen može da bude pogođen različitim tipovima mutacija, koje dovode do poremećaja funkcije proteina (Tabela 5) $(3,20)$. Do sada je opisano 150-200 mutacija ovog gena, što ukazuje na veliku alelsku heterogenost FH. Većinom su u pitanju mutacije tipične samo za jednu porodicu, koje se stoga nazivaju 


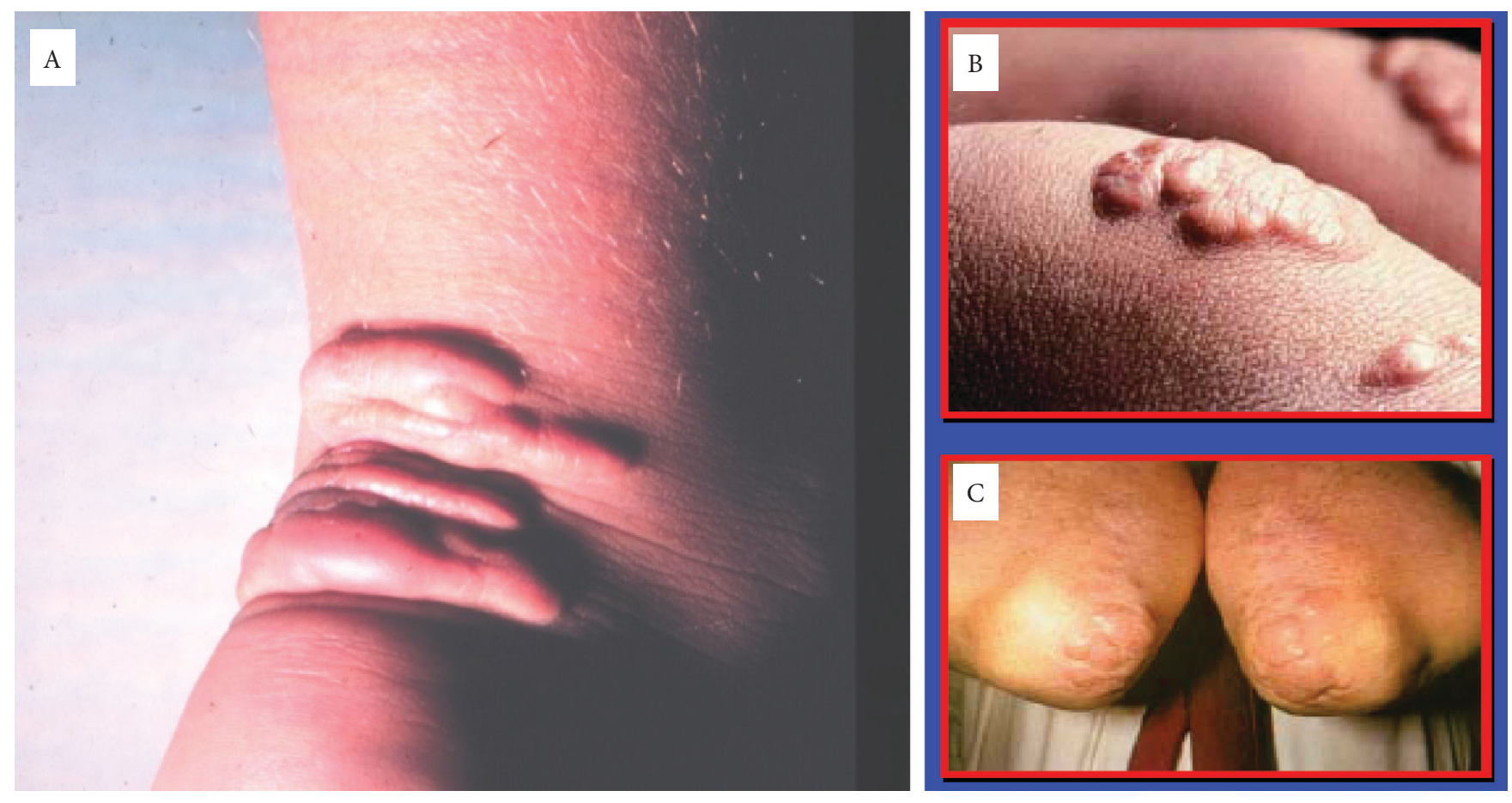

Slika 3. Promene na koži (ksantomi) izazvane povećanjem lipida u krv a) tetivni ksantomi; b) erupcijski ksantomi; c) tuberski ksantomi Izvor: http://en.wikipedia.org/wiki/Lipid - 0 lipidima

„privatne mutacije.“ Međutim, osobe koje imaju mutaciju na oba alela, označene klasično kao homozigoti, najčešće nose dve različite mutacije, pa su tzv. kompleksni heterozigoti. Zanimljivo je da u pojedinim populacijama postoje predominantni tipovi mutacija, što ukazuje na zajedničkog pretka, odnosno „efekat osnivača.“ Tako se velika delecija proksimalnog (5') kraja gena nalazi kod $60 \%$ obolelih iz francuskog dela Kanade, dok 35\% finskih bolesnika imaju deleciju od 9,5 kb u distalnom (3') regionu. Osim toga, besmislena (nonsens) mutacija u egzonu 14 karakteristična je za libanske hrišćane, a delecija od 3 bazna para u egzonu 4 uočava se kod Aškenazi Jevreja litvanskog porekla (20).

Heterozigotni oblik FH predstavlja relativno čest poremećaj koji postoji u približno $0,2 \%$ stanovništva. Ovaj oblik FH čini oko $10 \%$ primarnih hiperlipidemija. Nasuprot tome, homozigotni oblik FH je izuzetno redak (jedna obolela osoba na milion stanovnika). Laboratorijski pregledi pokazuju postojanje tipične fenotipske slike hiperlipidemije IIa po Fredriksonu (Tabele 1,

Tabela 9. Primarni poremećaji metabolizma lipoproteina velike gustine

\begin{tabular}{|c|c|c|c|}
\hline $\begin{array}{l}\text { Potpuni nedostatak } \\
\text { apolipoproteinaA-I (apoA-1) }\end{array}$ & $\begin{array}{l}\text { Odsustvo HDL u plazmi; pove- } \\
\text { ćanje SH u plazmi i tkivima }\end{array}$ & $\begin{array}{l}\text { Geni za apoA-I, apoA-II, apoA- } \\
\text { III, apoA-IV i apoA-V su na } \\
\text { hromozomu } 11\end{array}$ & $\begin{array}{l}\text { Ksantomi*; zamućenja rožnjače; } \\
\text { povećan rizik za rani početak } \\
\text { KVS\# }\end{array}$ \\
\hline Nedostatak apoA-I Milano & Niske vrednosti HDL u plazmi & $\begin{array}{l}\text { Vrednosti SH u plazmi i tkivi- } \\
\text { ma su povećane }\end{array}$ & $\begin{array}{l}\text { Zamućenje rožnjače; odsustvo } \\
\text { povećanog rizika za ranu KVS }\end{array}$ \\
\hline Tendžirska (Tangier) bolest & $\begin{array}{l}\text { Niska vrednost HDL; naku- } \\
\text { pljanje holesterola u RES }\end{array}$ & $\begin{array}{l}\text { Mutacija gena za ABCA1; bo- } \\
\text { lest je praćena ranom atero- } \\
\text { sklerozom\# }\end{array}$ & $\begin{array}{l}\text { Hepatosplenomegalija; krajni- } \\
\text { ci uvećani (sivo-žute ili oranž } \\
\text { boje); neurološki poremećaji }\end{array}$ \\
\hline $\begin{array}{l}\text { Potpuni (klasični) nedostatak } \\
\text { LHAT }\end{array}$ & $\begin{array}{l}\text { Količina SH u krvi i očnom so- } \\
\text { čivu je znatno povećana }\end{array}$ & $\begin{array}{l}\text { Mutacija gena za LHAT; veoma } \\
\text { nizak HDL u plazmi; hipertri- } \\
\text { gliceridemija }\end{array}$ & $\begin{array}{l}\text { Progresivno zamućenje rožnja- } \\
\text { če; hemolizna anemija; bubre- } \\
\text { žna slabost }\end{array}$ \\
\hline $\begin{array}{l}\text { Delimični nedostatak LHAT } \\
\text { - bolest riblje oko }\end{array}$ & $\begin{array}{l}\text { Količina SH u krvi i očnom so- } \\
\text { čivu je povećana }\end{array}$ & $\begin{array}{l}\text { Mutacija gena za LHAT; veoma } \\
\text { nizak HDL u plazmi; hipertri- } \\
\text { gliceridemija }\end{array}$ & Progresivno zamućenje rožnjače \\
\hline Homozigotni nedostatak CETP & Vrlo visok nivo HDL u plazmi & Mutacija gena za CETP & Javlja se uglavnom u Japanu \\
\hline Heterozigotni nedostatak CETP & $\begin{array}{l}\text { Umereno povećanje HDL u } \\
\text { plazmi }\end{array}$ & Mutacija gena za CETP & $\begin{array}{l}\text { Može se javiti u svim delovima } \\
\text { sveta }\end{array}$ \\
\hline $\begin{array}{l}\text { Primarna (familijarna) } \\
\text { hipoalfalipoproteinemija }\end{array}$ & $\begin{array}{l}\text { naziva se i izdvojen smanjen } \\
\text { HDL }\end{array}$ & $\begin{array}{l}\text { Obično je AD nasledni pore- } \\
\text { mećaj }\end{array}$ & $\begin{array}{l}\text { Mogući uzrok je ubrzana raz- } \\
\text { gradnja HDL }\end{array}$ \\
\hline
\end{tabular}

HDL- lipoproteini velike gustine (engl. high density lipoproteins); KVS- kardiovaskularne bolesti; ABCA1- ćelijski prenosnik koji olakšava transport neesterifikovanog holesterola i fosfolipida iz ćelija do apolipoproteinaA-1; RES- retikuloendotelni sistem; LHAT- lecitin holesterol acil transferaza; CETP- prenosni protein holesteril estra; AD- autozomno dominantno; SH- slobodni holesterol; \# - Slika 1; ${ }^{\star}$ - Slika 3 


Abetalipoproteinemija
Lipidni profil u plazmi:
Izrazito nizak holesterol i trigliceridi.
Odsustvo hilomikrona, lipoproteina
vrlo male gustine (VLDL), lipoproteina
male gustine (LDL) i apolipoproteina B
(apo B).

Familijarna hipobetalipoproteinemija

Volmanova (Wolman) bolest nakupljanje neutralnih masti $u$ ćelijama

\section{Sitosterolemija} Lipidni profil u plazmi:

U uzorcima plazme se detektuju povišeni nivoi sitosterola $i$ drugih biljnih sterola.

Koncentracije holesterola se kreću u fiziološkim granicama ili su povišene.
Retka autozomno recesivna (AR) bolest uzrokovana mutacijama gena za mikrozomski transportni protein triglicerida (MTP); obično se javlja u ranom detinjstvu; odlikuje je proliv, zaostajanje u razvoju, malapsorpcija masti, cerebelarna degeneracija, pigmentna retinopatija koja se pogoršava (najpre se manifestuje slabljenjem vida noću, a kasnije se gubi vid u potpunosti) i akantocitoza (nazubljen izgled eritrocita); većina ispoljavanja ove bolesti je posledica nedostatka apsorpcije i prenosa vitamina rastvorljivih u mastima; uočava se znatan nedostatak vitamina E i umeren nedostatak vitamina A i K; početna neurološka ispoljavanja obuhvataju gubitak dubokih tetivnih refleksa, smanjen osećaj vibracija i propriocepcije, dismetriju (neusmerenost pokreta), ataksiju (neusklađenost pokreta) i spastički hod.

Homozigotni poremećaj, obično uzrokovan mutacijama gena za apolipoprotein B-100 (apoB100), koji se ispoljava slično kao abetalipoproteinemija; nasleđuje se autozomno kodominantno.

AR bolest koja nastaje usled potpunog deficita lizozomske kisele lipaze; kod obolelih se javlja hepatosplenomegalija, steatoreja, kalcifikacija nadbubrega, zaostajanje u razvoju i smrtni ishod u prvoj godini života.

Retka AR bolest uzrokovana mutacijama u jednom od dva člana familije adenozin trifosfat (ATP)-vezujućih kasetnih prenosnika (ABCG5 i ABCG8); ovi geni se ispoljavaju u crevima i jetri, gde stvaraju funkcijski kompleks za ograničavanje crevne apsorpcije i podsticanje izlučivanja neutralnih sterola biljnog i životinjskog porekla putem žuči. Normalno su količine biljnih sterola u plazmi veoma niske. Međutim, u bolesnika crevna apsorpcija biljnih sterola je povećana, a izlučivanje putem žuči je smanjeno; kožni i tetivni ksantomi* i rana ateroskleroza\#; svojstvena odlika ove bolesti su naleti hemolize, najverovatnije zbog ugradnje biljnih sterola u opnu eritrocita.

\# - Slika 1; * Slika 3

2, 4 i 6) (3). Najznačajnije je da kod bolesnika postoji rani početak ateroskleroze (Slike 1 i 2$)(3,20)$. Lekari se u svojoj praksi susreću uglavnom sa pacijentima heterozigotima, čiji potomci imaju $50 \%$ rizik da naslede mutaciju, pa time i oboljenje $(3,19,20)$. S obzirom da je kod heterozigota smanjen broj LDL receptora na polovinu, značajno je otežan ulazak LDL čestica u ćelije, što za posledicu ima nagomilavanje LDL čestica u krvi

\section{Nobel Prize Alert: 1985}

\section{A Receptor-Mediated Pathway for Cholesterol Homeostasis}

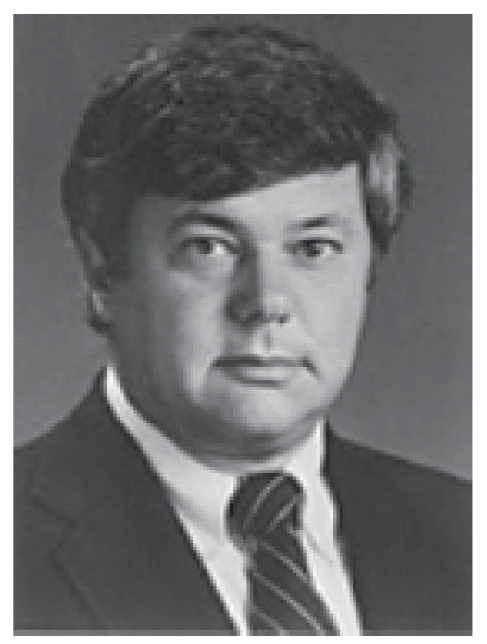

Michael S. Brown

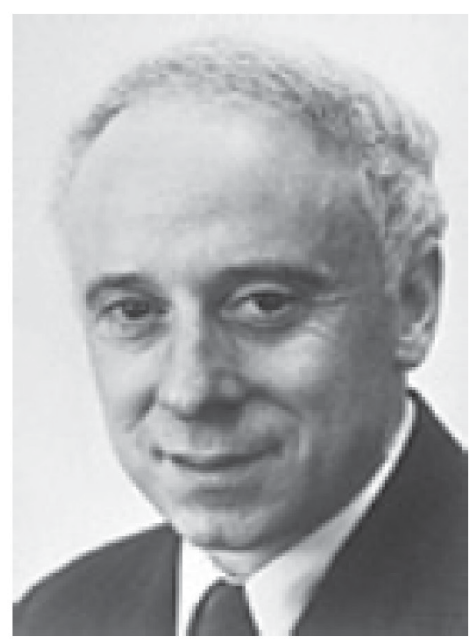

Joseph Goldstein 


\section{The LDL receptor}

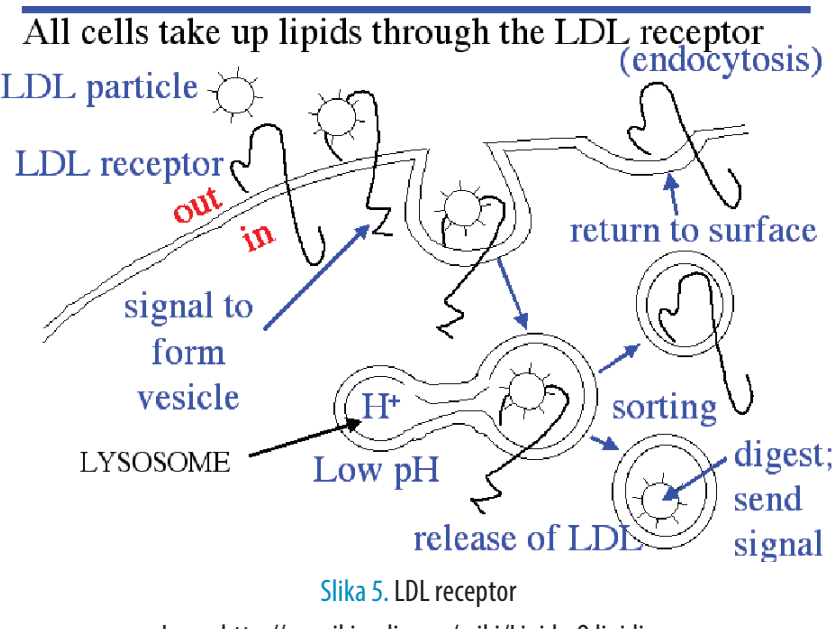

Izvor: http://en.wikipedia.org/wiki/Lipid - 0 lipidima

i njihovo nagomilavanje u monocitima, makrofagima i vaskularnim glatkim mišićnim ćelijama posredstvom receptora čistača (engl. scavenger receptors) (Slika 1) (3). Slično tome, kod homozigota, postoji potpuni nedostatak ćelijskih LDL receptora $(3,15)$. Zbog toga se holesterol nakuplja pre svega u zidovima koronarnih arterija, a potom i moždanih i perifernih arterija, $s$ fatalnim posledicama u smislu razvoja teške ateroskleroze (Slika 2) (3). Do pojave infarkta miokarda kod heterozigota obično dolazi oko četrdesete godine života $(3,15)$. Suprotno tome, u homozigotnih osoba infarkt miokarda nastaje već u drugoj ili trećoj deceniji života, a opisivani su i infarkti kod dece mlađe od deset godina $(3,20)$. Relativno često dolazi i do teške stenoze aortnog ušća usled stvaranja depoa masti u zidu aorte i ispod samih aortnih zalistaka leve srčane komore (3). Uz to, relativno često se stvaraju velike naslage holesterola u obliku čvorastih formacija u koži, tetivama (Slika 3) i na očnim kapcima $(3,15,20)$. Uočava se, takođe, i zamućena prstenasta formacija na rožnjači oka (3).

Interesantno je pomenuti da su osobe $\mathrm{s} F H$ najčešće normalno uhranjene ili mršave (3). Pošto se hiperholestrolemija javlja još u detinjstvu, rano otkrivanje poremećaja omogućava primenu adekvatne terapije i režima ishrane u najranijoj fazi (20). Iz samog naziva oboljenja jasno je da se u porodicama ovih bolesnika redovno nalaze slični poremećaji, ili u jednog ili u oba roditelja i bliskih srodnika $(3,19)$.

Imajući u vidu da je FH najopasniji prekursor koronarne bolesti (FH se sreće kod 5\% slučajeva infarkta miokarda ispod 60. godine života), neophodno je u praksi pravovremeno registrovati prisutnu funkcijsku klasu mutacija gena za LDL receptor. S tim u vezi, u funkcijskom smislu otkriveno je pet klasa mutacija gena za LDL receptor. U prvoj klasi su mutacije gena koje dovode do potpunog odsustva sinteze proteina. Te mutacije se mogu naći na različitim mestima u genu. Ovoj grupi pripada oko 20\% mutacija. Drugu klasu čine mutacije koje omogućavaju sintezu proteina, ali blokiraju trans- port LDL receptora od endoplazmatskog retikuluma do Goldžijevog aparata. Ovo je najbrojnija grupa, kojoj pripada preko $50 \%$ mutacija. Više od polovine homozigota, tj. kompleksnih heterozigota imaju bar na jednom alelu ovaj tip mutacije. U ovoj klasi $2 / 3$ mutacija pogađaju $\mathrm{N}$-terminalni domen za vezivanje sa ligandom. U trećoj klasi mutacija receptor je normalno prisutan na površini ćelije, ali postoji poremećaj u vezivanju liganda. To su insercije ili delecije, koje se odnose na prvi ili drugi domen proteina. Kod promena u prvom domenu, receptor smanjuje vezivanje LDL, koje se ostvaruje samo preko apoproteina-B 100, pri čemu je normalno vezivanje IDL preko apoproteina-E. Izuzetak čini teži fenotip, kada je poremećeno vezivanje i LDL i IDL čestica. Četvrtu klasu čine mutacije koje omogućavaju normalnu sintezu receptora i njegovo vezivanje sa ligandom. Međutim, receptor nije pravilno smešten u jamice, a to su udubljenja obložena klatrinom. Iz tog razloga nije moguće unošenje liganda u ćeliju. U okviru ove klase mutacija, može se zapaziti i kompletan izostanak ugradnje receptora u membranu, kada se oko $90 \%$ proteina sekretuje van ćelije. U pitanju su različiti tipovi mutacija koje pogađaju transmembranski ili citoplazmatski domen proteina. U poslednjoj petoj klasi se nalaze mutacije koje omogućavaju sve prethodne faze, tj. sintezu receptora, njegovu pravilnu lokalizaciju, vezivanje i unošenje liganda, ali postoji poremećaj u fazi recikliranja receptora i njegovog vraćanja na membranu. Oko $20 \%$ homozigota, tj. kompleksnih heterozigota pripada ovoj grupi. Obično je u pitanju ugradnja pogrešne aminokiseline u području drugog domena receptora (20).

Kao što se može uočiti, podela genskih mutacija na pet klasa ima direktne veze sa tipom oštećenja funkcije LDL receptora, pa samim tim i sa ćelijskim i kliničkim fenotipom (20). U načelu, bolesnici kod kojih je receptor prisutan, ali je smanjene funkcije, imaće niže vrednosti LDL holesterola, blažu kliničku sliku i bolji odgovor na terapiju u poređenju sa bolesnicima kod kojih je receptor potpuno nefunkcionalan ili odsutan $(3,15,20)$. Međutim, zapaženo je da u jednoj porodici u kojoj svi oboleli nose isti tip mutacije mogu da postoje značajne varijacije u kliničkom toku bolesti. To se može objasniti efektima koje ispoljavaju drugi geni-modifikatori ili faktori sredine. Ilustrativan je primer porodice u kojoj $1 / 3$ heterozigota sa dokazanom mutacijom ima normalne vrednosti LDL (20).

Primenom savremenih metoda molekularne genetike moguće je izvršiti direktnu ili indirektnu detekciju mutacija u genu za LDL receptor $(19,20)$. Direktna analiza omogućava identifikaciju mutacije i shodno tome potvrdu dijagnoze kod obolelih osoba i skrining među ostalim članovima porodice, kao i prenatalnu dijagnostiku FH. Međutim, zbog veličine gena za LDL receptor, kao i zbog velike alelske heterogenosti mutacija, direktna analiza nije jednostavna. Indirektna dijagnostika ili linkage analiza podrazumeva praćenje nasleđivanja 
Tabela 11. Najčešći uzroci sekundarnih hiperlipidemija

Metabolički poremećaji
Šćerna bolest, gojaznost, giht, metabolički sindrom, glikogenoze, i dr.
Endokrine bolesti
Hipotireoidizam, hipopituitarizam, akromegalija, Kušingov (Cushing) sindrom, i dr.
Bolesti jetre
Akutni i hronični hepatitis, holestaza, primarna bilijarna ciroza, hepatocelularni karcinom, i dr.
Bolesti bubrega
Hronična bubrežna insuficijencija, nefrotski sindrom, stanja posle transplantacije bubrega, i dr.
Egzogeni uzroci
Nepravilna ishrana, alkohol, lekovi (oralna kontracepcijska sredstva, tiazidni diuretici, beta-blokatori, kortikosteroidi i drugi imuno-
supresivi).
Disproteinemije
Plazmocitom, makroglobulinemija, sistemski eritemski lupus (SLE), amiloidoza, i dr.
Ostali uzroci
Trudnoća, neke infekcije, smanjena fizička aktivnost, pušenje duvana, stres, pothranjenost, analbuminemija, akutna intermitentna
porfirija, idiopatska hiperkalcemija, hiperparatireoidizam, Štajn-Leventalov (Stein-Leventhal) sindrom (sindrom uvećanih policističnih
jajnika), feohromocitom i dr.

polimorfnih DNK markera, koji se nalaze u okviru ili blizini gena odgovornog za bolest. Ovaj tip ispitivanja je uvek porodični. Najpre se utvrdi koju formu markera poseduju obolela osoba ili osobe, a zatim se praćenjem nasleđivanja tog markera u porodici posredno (idirektno) zaključuje da li je pojedini član porodice nasledio mutaciju. Ova analiza se može primeniti i u svrhu prenatalne dijagnostike (20).

\section{SEKUNDARNE HIPERLIPIDEMIJE}

Sekundarne hiperlipidemije nastaju zbog pojačanog stvaranja ili smanjene razgradnje lipoproteinskih čestica, kao propratna pojava brojnih bolesti ili usled delovanja različitih spoljnjih činilaca (Tabela 11) $(4,21)$. Procenjuje se da sekundarne hiperlipidemije čine čak $90 \%$ svih hiperlipidemija, pri čemu su najzastupljenije one koje su posledica nepravilne ishrane (21). U kliničkom

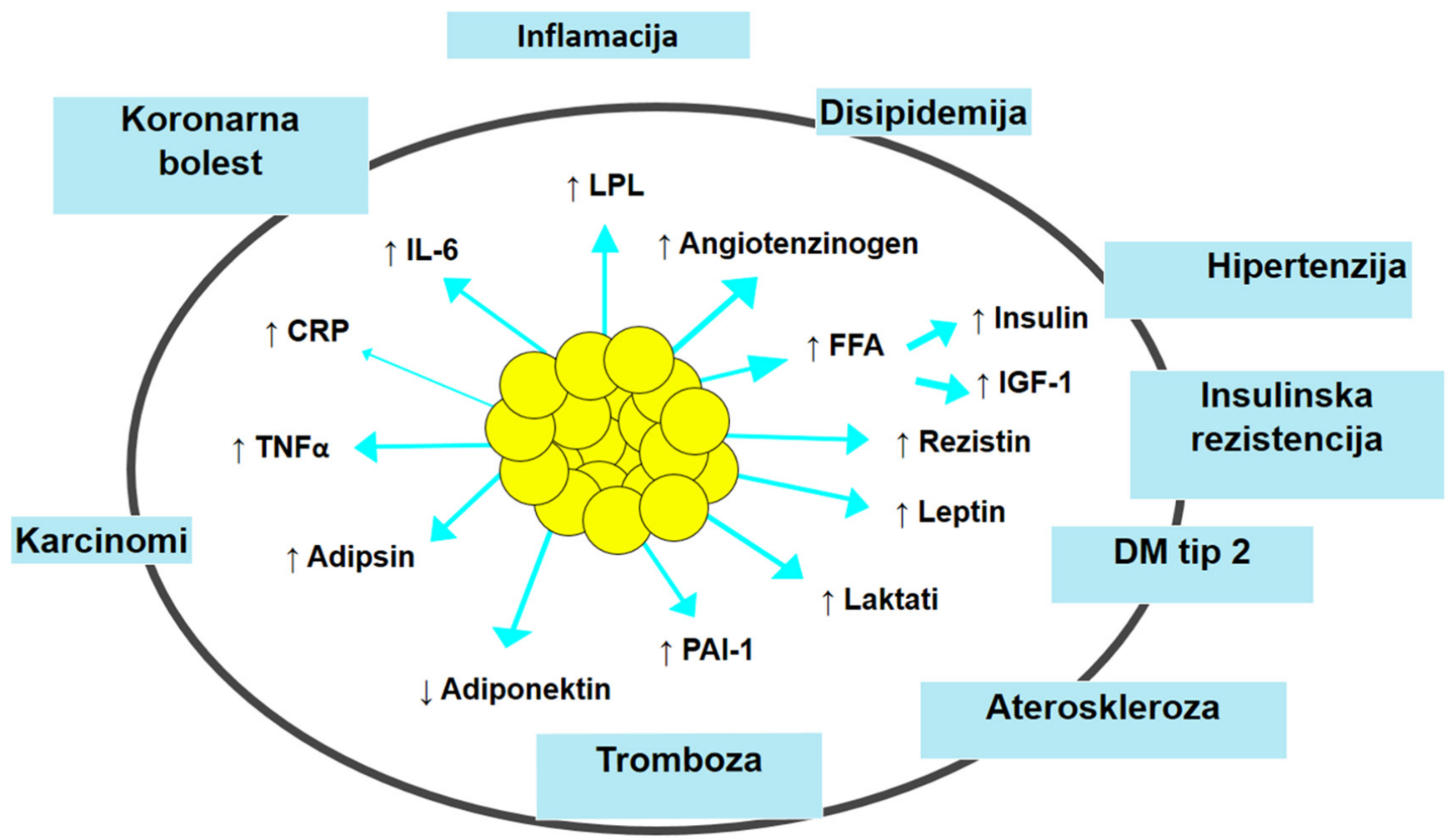

Slika 6. Biološki aktivni molekuli koje sekretuju adipociti (8)

LPL- lipoproteinska lipaza; IL-6 - interleukin- 6; (RP- C reaktivni protein;

TNFa- faktor tumorske nekroze a; PAl-1 -inhibitor-1 aktivatora plazminogena

FFA (engl. free fatty acids)- slobodne masne kiseline; DM- dijabetes melitus IGF-1 (engl. insulin-like growth factor-1) insulinu sličan faktor rasta-1 
pogledu mogu se ispoljiti u obliku svih šest tipova Fredriksonove klasifikacije hiperlipidemija, obično u blažoj formi nego primarne $(3,15,21)$. Razlikovanje primarnih od sekundarnih hiperlipidemija je neophodno za pravilno lečenje $(1,21)$. Sekundarne hiperlipidemije se koriguju lečenjem osnovnog poremećaja $(1,4,21)$. Treba istaći da je često reč o udruženom postojanju primarne i sekundarne hiperlipidemije, tako da sekundarna hiperlipidemija pogoršava već postojeću primarnu hiperlipidemiju (21). U odnosu na KVS i CVS, sekundarne hiperlipidemije su slično primarnim hiperlipidemijama važan faktor rizika $(1,4,12)$.

Nepravilna ishrana ima dvostruku ulogu u razvoju hiperlipidemija (4). Ona prvenstveno dovodi do razvoja sekundarnih hiperlipidemija, a često je i dodatni faktor koji pogoršava već postojeći, ponekad i relativno blagi, nasledni poremećaj metabolizma masti $(4,21)$. Pri tome su od značaja ne samo vrsta unete hrane, već i celokupni energetski unos, s obzirom da se u slučaju preobilne ishrane razvija gojaznost, koju često prati povišena koncentracija lipida u krvi $(1,21)$. Metaboličkom disbalansu neposredno doprinose i citokini koji se stvaraju u masnom tkivu (Slika 6) (8). Oni olakšavaju nastanak dislipidemija i na posredan način, svojim negativnim uplivom na endotelne ćelije krvnih sudova (ubrzano stvaranje ateroma) i ćelije u mišićnom tkivu (olakšan razvoj periferne insulinske rezistencije) (Slika 6) $(8,21$, 22). Povećano unošenje holesterola, zasićenih masnih kiselina, kao i trans izomera nezasićenih masnih kiselina uzrokuje povećanje koncentracije holesterola u krvi (3). Konzumiranje velike količine kafe, takođe može da dovede do hiperholesterolemije, dok povećan unos koncentrovanih ugljenih hidrata povećava koncentraciju TG, a snižava nivo HDL (21). Pušenje duvana izaziva sniženje nivoa HDL u krvi, i to u proseku za 0.1-0.3 $\mathrm{mmol} / \mathrm{L}(18,21)$.

Alkohol, čak i kad se u organizam unosi u umerenim količinama, je čest uzrok sekundarnih hiperlipidemija, koje se povlače posle prekida njegovog unosa (21). U toku uzimanja alkohola naročito dolazi do povišenja nivoa TG i HDL u krvi (4). Međutim, to povećanje koncentracije $\mathrm{HDL}$ se ne ostvaruje na račun zaštitne $\mathrm{HDL}_{2}$, već aterogene $\mathrm{HDL}_{3}$ subfrakcije $(18,21)$. Preterano uzimanje alkohola smanjuje oksidaciju, a povećava nastanak redukovanog oblika nikotinamid adenin dinukleotida (NADH), koji podstiče sintezu masnih kiselina u jetri, čiji se višak esterifikuje u TG (21). Pri tom se deo nastalog viška TG nakuplja u jetri, pa nastaje karakteristična masno promenjena jetra alkoholičara, dok se ostatak TG u obliku VLDL izlučuje u krv uzrokujući hipertrigliceridemiju $(21,23)$. U nekih alkoholičara, pored vrlo visokih vrednosti TG, dolazi do nakupljanja i HM $(24,25)$. Alkoholičari sa ovim vidom hiperlipidemije često oboljevaju od akutnog pankreatitisa $(21,23)$. U etiličara koji imaju porodičnu hiperlipoproteinemiju, uzimanje alkohola dovodi do prave egzacerbacije TG u plazmi (4). U izraženoj alkoholnoj hiperlipidemiji često se mogu uočiti erupcijski ksantomi (koža) (Slika 3b) i lipemijski retinitis (zapaljenje mrežnjače oka) (21).

Lekovi - Neki lekovi, ukoliko se uzimaju u većoj količini u dužem vremenskom periodu, mogu dovesti do sekundarne hiperlipidemije (21). Tako, na primer, $\boldsymbol{g l u}$ kokortikoidi, beta-blokatori i tiazidni diuretici uzrokuju povećanje VLDL i LDL u krvi (4, 21). Slično tome, ciklosporin, koji spada u grupu imunosupresijskih lekova, svoj uticaj na hepatocite ispoljava u vidu smanjenog katabolizma LDL, što dovodi do povećanja LDL u krvi (21). Osim toga, oralna kontracepcijska sredstva povećavaju sintezu VLDL i njiihovo oslobađanje u krv, pri čemu kod većine žena nastaje neznatna hipertrigliceridemija, jer se istovremeno povećava katabolizam TG (4, 21). Međutim, u žena kod kojih je dijagnostikovana porodična hipertrigliceridemija ili porodična kombinovana hiperlipidemija, upotreba oralnih kontracepcijskih lekova može povećati katabolizam VLDL, pa dolazi do izražene hipertrigliceridemije $(3,21,23)$. U retkim slučajevima može da se javi i hiperhilomikronemija (21). Zbog toga je neophodno da se u cilju sprečavanja začeća kod ovih žena primenjuju noviji kontracepcijski preparati, koji imaju povoljno dejstvo na lipidni status $(3,21)$. Osim toga, na lipidni status značajno utiču i steroidi polnih žlezda. S tim u vezi, pokazano je da per $o s$, parenteralno ili transkutano davanje estrogena smanjuje koncentraciju LDL, najverovatnije povećavajući aktivnost njihovih receptora (21). Utvrđeno je, takođe, da oralna primena androgena dovodi do povećanja LDL usled smanjene aktivnosti LHAT, kao i smanjenja HDL i TG, zbog pojačane aktivnosti jetrine LPL $(15,21)$. Pored toga, epidemiološke studije su potvrdile da su žene u pogledu lipoproteinskog sastava u mnogo povoljnijem položaju u odnosu na nastanak koronarne bolesti, nego što je to slučaj sa muškarcima $(3,21)$. Tako, žene u poređenju sa muškarcima imaju veću koncentraciju HDL u pubertetu $(18,21)$. Uz to, u odnosu na muškarce, žene u toku čitavog života imaju nižu koncentraciju VLDL, dok im je koncentracija LDL manja sve do šeste decenije starosti $(14,21)$.

Mehanizmi nastanka sekundarnih hiperlipidemija u okviru različitih bolesti su raznovrsni i uslovljeni prirodom same bolesti (21). Tako je, šećerna bolest (dijabetes melitus/diabetes mellitus/) često udružena s poremećajem metabolizma masti, pri čemu mehanizam nastanka tih poremećaja zavisi od tipa dijabetesa $(4,21)$. Kod obolelih od dijabetesa tip 1 lipidi u krvi su obično normalni kada je terapija insulinom odgovarajuća. Međutim, kada je terapija neadekvatna ili pre započinjanja terapije insulinom dolazi do pojave izrazite hipertrigliceridemije, uz relativno često istovremeno povećanje nivoa UH i LDL (21). U takvim uslovima, u kojima dominira apsolutni i/ili relativni nedostatak insulina povećano je oslobađanje masnih kiselina iz adipocita (Slika 6), iz kojih se u jetri sintetišu TG, tako da je 
zbog toga u hepatocitima povećano stvaranje VLDL (21, 26). S druge strane, u perifernim tkivima je zbog nedostatka insulina smanjena aktivnost LPL, a time i razgradnja VLDL, što za posledicu ima povećanje VLDL u krvi i nastanak izrazite hipertrigliceridemije (21). Pored toga, glikozilacija (ugradnja šećera u proteine) dovodi do smanjenja aktivnosti LDLR i nagomilavanja LDL čestica u cirkulaciji (Slika 1) $(8,21)$. Osim toga, hiperglikemija je okidač kaskadnih mehanizama koji dovode do oslobađanja reaktivnih kiseoničkih vrsta, pa se na taj način dodatno ubrzava i olakšava aterogeneza (Slika 7) (8). Hipertrigliceridemija je takođe ispoljena u preko $50 \%$ bolesnika koji imaju dijabetes tip 2, s obzirom da rezistencija na insulin snažno stimuliše jetru na lučenje povećane količine TG i VLDL $(8,27)$. Prisutna je i hiperholesterolemija, koja se dovodi u vezu sa smanjenom sposobnošću izmenjenih LDL čestica (najzastupljenija je izrazito aterogena subpopulacija $\mathrm{LDL}_{3}$ ) za vezivanje za specifične receptore (21). Aterogenom lipidnom profilu ovih bolesnika pridonosi i naglašeno sniženje HDL u krvi $(8,21)$. Značajno je da lipoproteinski poremećaji mogu perzistirati i posle postizanja dobre metaboličke kontrole dijabetesa, tj. $\mathrm{u}$ fazama bolesti koje odlikuje dobra glikoregulacija (21). Osim toga, trajno visoki nivo TG viđa se u gojaznih dijabetičara i u onih koji imaju porodičnu formu hipertrigliceridemije $(8,21)$. U tim slučajevima, koje često prati i pojava erupcijskih ksantoma (Slika 3b), lipemijskog retinitisa i hepatomegalije, pored lečenja dijabetesa, potrebna je i medikamentna terapija hiperlipidemije (21).
Gojaznost je često udružena s poremećajima metabolizma masti, posebno u okviru centralnog ili abdominalnog tipa gojaznosti kojeg karakteriše nagomilavanje masnog tkiva u predelu trbuha, odnosno oko unutrašnjih organa (21). U gojaznih osoba je zbog prisustva insulinske rezistencije izražena hipertrigliceridemija (Slika 6) (3, 28). Uz to, u jetri i hipertrofijski izmenjenom masnom tkivu povećava se sinteza holesterola, pri čemu su najviše zastupljene male, guste i veoma aterogene $\mathrm{LDL}_{3}$ čestice (21). Istovremeno, usled povećane razgradnje HDL u masnom tkivu, kao i prateće hipertrigliceridemije koja remeti obrnuti transport holesterola, dolazi do smanjenja koncentracije zaštitnih HDL čestica $(8,21)$.

Hipertrigliceridemija, koja se uočava u preko $60 \%$ obolelih od gihta (hiperurikemije), u najvećem broju slučajeva nastaje usled rezistencije na insulin (21). To je ujedno i najčešći mehanizam nastanka hipertrigliceridemije u obolelih od metaboličkog sindroma $\mathbf{X}$ plus, kojeg odlikuje intolerancija glukoze, dislipidemija, arterijska hipertenzija, abdominalna gojaznost i hiperurikemija $(8,21)$.

Hipotireoidizam je praćen izrazitim povećanjem holesterola u krvi $(4,21)$. Osnovni uzrok nastanka izmene lipidnog statusa u plazmi obolelih od hipotireoidizma je smanjena potrošnja kiseonika, odnosno oslabljena oksidacijska fosforilacija u organizmu $(15,21)$. U takvim uslovima, usled smanjene oksidacije masnih kiselina, dolazi do veće sinteze TG i pojačane sekrecije VLDL (15). S obzirom da su tireoidni hormoni značajni za sin-

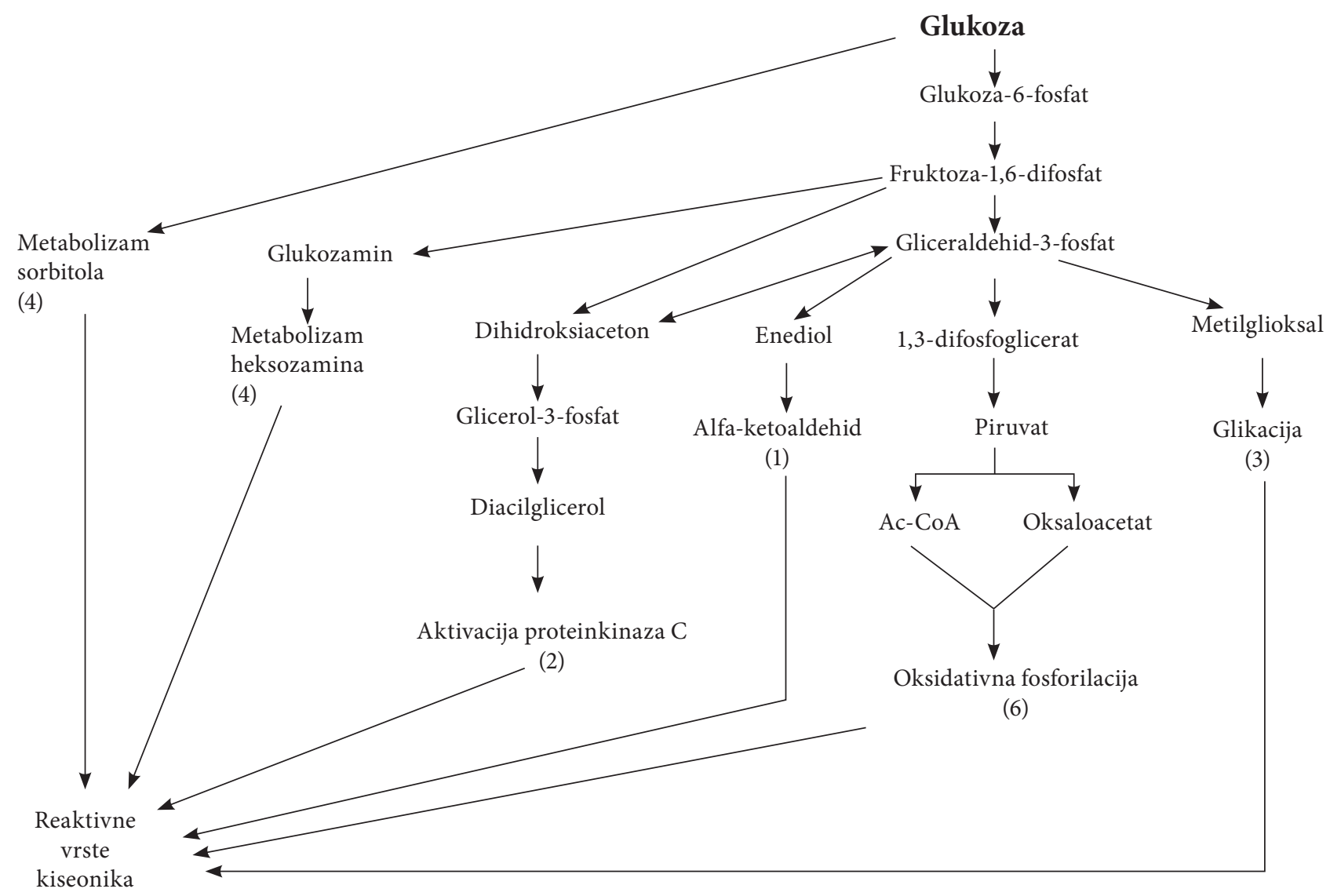

Slika 7. Stvaranje reaktivnih kiseoničkih vrsta u hiperglikemiji (8) 
tezu LDLR, njihov nedostatak dovodi do sekundarnog, reverzibilnog smanjenja broja i aktivnosti ovih receptora, kao i usporenog katabolizma LDL i IDL, pa nastaje povećanje UH, LDL, apo-B i beta-lipoproteina (21). Takođe, nije redak slučaj da se u toku dijagnostikovanja koronarne bolesti, naročito u dijabetičara i žena starijih od 50 godina, otkrivaju subkliničke forme hipotireoze, koje se ispoljavaju povišenim vrednostima tireostimulacijskog hormona (TSH) i početnim promenama metabolizma masti $(15,21)$.

Povišena koncentracija VLDL i LDL se najčešće uočava u krvi osoba koje imaju povećanu funkciju nadbubrežne žlezde (Kušingov /Cushing/ sindrom) $(4,21)$. Kod ovih bolesnika glukokortikoidi povećavaju oslobađanje VLDL iz jetre i oštećuju LDLR (21). Na taj način nastaje porast ne samo koncentracije LDL, već i UH $(3,14)$. Postoji i ubrzan katabolizam HDL, koji dovodi do smanjenja sadržaja ovih lipoproteinskih čestica (21).

Oboljenja jetre - Kod oboljenja jetre u zavisnosti od stepena oštećenja njene funkcije, hiperlipidemija se može ispoljiti na različite načine $(4,15,21,27)$. Tako, u bolesnika s holestazom, koja nastaje usled mehaničke opstrukcije ili primarne bilijarne ciroze, dolazi do regurgitacije fosfolipida i holesterola iz bilijarnog trakta u cirkulaciju, što je praćeno povećanjem nivoa holesterola i stvaranjem lipoproteina X (LpX) (21). Ovaj patološki oblik lipoproteina, koji je po gustini sličan LDL čestici, sastoji se od neesterifikovanog holesterola i fosfolipida $(21,29)$. Prekomerno prisustvo LpX čestica dovodi do ateroskleroze (Slika 1) i ksantomatoze (Slika 3) $(3,21)$. Uz to, usled izmene holesterola iz LpX i lecitina iz eritrocita, u obolelih od holestaze može nastati i hemolitička anemija (21). S druge strane, nakupljanje VLDL u krvi, uzrokovano smanjenom sintezom i lučenjem LHAT, predstavlja glavnu promenu lipidnog statusa obolelih od akutnog hepatitisa, dok je nekontrolisano nagomilavanje LDL u cirkulaciji, izazvano ispadom funkcije negativne povratne sprege zadužene za sintezu ovih lipoproteinskih čestica, dominantna karakteristika lipidnog profila obolelih od hepatocelularnog karcinoma $(21,27)$. Međutim, u terminalnom stadijumu navedenih bolesti jetre dolazi do pada koncentracije lipida u krvi, zbog onemogućene sinteze i sekrecije VLDL i HDL čestica (21).

Oboljenja bubrega - Kombinacija povećanog stvaranja i smanjene razgradnje lipoproteinskih čestica predstavlja mogući uzrok nastanka sekundarne hiperlipidemije u nefrotskom sindromu (21). Tom prilikom, razvija se hipoproteinemija, koja narušava održavanje koloidnoosmotskog pritiska i istovremeno dovodi do povećane sinteze i oslobađanja VLDL iz hepatocita, kao i usporenog katabolizma VLDL i LDL partikula (kompenzacijska hiperlipidemija) (21, 23). Slično tome, nakupljanje VLDL čestica i posledična hipertrigliceridemija, koja nastaje zbog smanjene aktivnosti LPL, uočava se u krvi obolelih od hronične bubrežne insuficijencije $(15,21)$. Osim toga, bolesnike na hemodijalizi odlikuje ubrzana aterogeneza, kojoj doprinosi povećano prisustvo IDL čestica, praćeno sniženjem koncentracije HDL u krvi (21).

Disproteinemije - U osoba koje boluju od SLE vezivanje imunoglobulina (Ig) G i M klase za heparin može da smanji aktivnost LPL, što je praćeno pojavom sekundarne hiperlipidemije, koja se manifestuje povećanjem nivoa HM u krvi $(4,21)$. Sekundarne hiperlipidemije se javljaju i u sklopu monoklonskih gamapatija (mijeloma, makroglobulinemija, limfoma), kao posledica vezivanja IgG, odnosno IgM za IDL i VLDL čestice (15, 21). Stvoreni kompleksi, potom, usporavaju katabolizam tih čestica, zbog čega se one nakupljaju u krvi (21).

U trudnoći se usled hiperestrogenemije povećava koncentracija LDL, VLDL i HDL u krvi, pri čemu se lipidni status normalizuje nakon porođaja (21).

U pothranjenih osoba (osobe kod kojih je ustanovljena anorexia nervosa) smanjeno lučenje holesterola i žučnih kiselina dovodi do nakupljanja LDL čestica u krvi, usled čega nastaje paradoksalna ili transportna hiperlipidemija (21).

Normolipidemijske dislipoproteinemije - Poremećaji pojedinih vrsta lipoproteina ili njihovih subfrakcija, pri čemu su u krvi prisutne normalne koncentracije holesterola i TG, označavaju se terminom normolipidemijske dislipoproteinemije $(3,21)$.

Nizak nivo HDL (hipoalfalipoproteinemija) spada u ove poremećaje i predstavlja vrlo ozbiljan faktor rizika za nastanak ateroskleroze i njenih komplikacija $(3,21$, 30). Ovaj poremećaj može da nastane u nekim posebnim okolnostima, kao što su pušenje, nedovoljna fizička aktivnost, gojaznost i dugotrajna upotreba nekih lekova (oralna kontracepcijska sredstva, beta-blokatori, anabolički steroidi, i dr.) (21). Međutim, opisani su i slučajevi izolovano niskih vrednosti HDL u krvi članova određenih porodica, uz potpuno normalne vrednosti $\mathrm{UH}, \mathrm{TG}$ i drugih vrsta lipoproteina $(3,21)$.

Povišen nivo lipoproteina-a /Lp(a)/, tj. hiperLp(a)lipoproteinemija je drugi poremećaj iz ove grupe, koji predstavlja faktor rizika za nastanak ateroskleroze $(8$, 21). Štaviše, ustanovljena je tesna veza između njegovih povišenih koncentracija u krvi i koronarne bolesti nezavisno od drugih faktora rizika $(3,21)$. Normalne koncentracije $\mathrm{Lp}(\mathrm{a}) \mathrm{u} \mathrm{krvi}$ su ispod $0.25 \mathrm{~g} / \mathrm{L}$, vrednosti 0.25 $0.50 \mathrm{~g} / \mathrm{L}$ su povišene, a iznad $0.50 \mathrm{~g} / \mathrm{L}$ izrazito povišene (21). Povećanje koncentracije Lp(a) predstavlja čest i vrlo ozbiljan nasledni poremećaj koji se ne ispoljava kliničkim simptomima i znacima, pa je njegovo otkrivanje isključivo u domenu laboratorijske dijagnostike $(3,21)$. Njegovo određivanje u krvi može poslužiti kao svojevrstan marker za otkrivanje osoba s visokim rizikom za 
nastanak koronarne bolesti (21). To je od posebne važnosti u porodicama bolesnika koji su doživeli infarkt miokarda u mlađim i srednjim godinama života $(3,21)$.

Postprandijalna lipemija podrazumeva nagomilavanje u krvi lipoproteinskih čestica bogatih TG nakon uzimanja obroka bogatih mastima $(3,21,31)$. Ova pojava se uočava i u zdravih osoba, s tim što se lipoproteinske čestice potpuno gube iz cirkulacije 6-8 časova posle konzumiranja masnog obroka $(21,31)$. Međutim, u nekih osoba takvo stanje se održava znatno duže (u proseku između 10 i 12 časova), kao izraz usporene razgradnje lipoproteinskih čestica bogatih TG, do koje prvenstveno dovodi insulinska rezistencija, a zatim i ostali uzročnici (smanjenje aktivnosti LPL, abdominalni ili centralni tip gojaznosti, preobilni obrok bogat životinjskim mastima, povećan unos hranom trans izomera nezasićenih masnih kiselina, nedovolina fizička aktivnost, neki genetski poremećaji, i dr.) (21). Na osnovu brojnih eksperimentalnih, epidemioloških i kliničkih studija ustanovljeno je da postprandijalna lipemija dovodi do ubrzanog razvoja ateroskleroze i koronarne bolesti u osoba s normalnim ili lako povišenim vrednostima lipida i lipoproteina u krvi $(21,31,32)$.

\section{ZAKLJUČAK}

Uprkos neprekidnom ovladavanju biomedicinskim znanjima i tehnikama, naučnici su još uvek daleko od potpunog razumevanja etiopatogeneze hiperholesterolemija.
Imajući u vidu tendenciju sve većeg porasta prevalencije poremećaja metabolizma lipida u narednim dekadama, neophodno je preduzimanje preventivnih mera za suzbijanje faktora rizika na koje se može uticati (nepravilna ishrana bogata ugljenim hidratima i zasićenim masnim kiselinama, gojaznost, pušenje duvana, sedentarni način života i fizička neaktivnost). U slučajevima kada se promenom stila života, hipokalorijskom dijetom i povećanjem fizičke aktivnosti ne postigne normalizacija lipidnog statusa, uz nastavak primene ovih mera neophodna je i medikamentna terapija hiperlipidemija.

Kao što je ranije već rečeno, lečenje sekundarnih hiperlipidemija prvenstveno se sastoji u otklanjanju i/ili tretmanu osnovnog oboljenja ili poremećaja koji je doveo do hiperlipidemije. Međutim, otklanjanje uzročnika jedne sekundarne hiperlipidemije ne normalizuje uvek i lipidni status, s obzirom da se često radi o kombinaciji primarnih hiperlipidemija i nekog od brojnih uzroka sekundarnih oblika bolesti. Stoga su potrebna dalja istraživanja molekulskih mehanizama ovih metaboličkih poremećaja, kako bi se sprečio njihov nastanak, odnosno pronašao efikasniji terapijski pristup.

\section{NAPOMENA}

Ovaj rad je finansiran sredstvima iz projekta broj 175015 Ministarstva prosvete, nauke i tehnološkog razvoja Republike Srbije.

\section{Literatura}

1. Baron RB. Lipid disorders. In: McPhee SJ, Papadakis MA, editors. Current medical diagnosis and treatment. New York: McGraw-Hill; 2016. p. $1239-48$.

2. Sinderman AD. The severe hypercholesterolemia phenotype: clinical diagnosis, management and emerging therapies. J Am Coll Cardiol 2014; 63:1935-47.

3. Lepšanović L, Lepšanović Lj. Povišeni holesterol i ateroskleroza. 2. dopunjeno i izmenjeno izd. Beograd: Velarta; 2009.

4. Republička stručna komisija za izradu i implementaciju vodiča dobre kliničke prakse, Odbor za lipide Endokrinološke sekcije Srpskog lekarskog društva, Udruženje za aterosklerozu Srbije, Ministarstvo zdravlja Republike Srbije. Nacionalni vodič dobre kliničke prakse za dijagnostikovanje i lečenje lipidskih poremećaja. Beograd: Agencija za akreditaciju zdravstvenih ustanova Srbije; 2012.

5. Vučević D, Radak Đ, Radosavljević T, Mladenović D, Milovanović I. Zapaljenski proces u aterogenezi: nove činjenice o starom plamenu. Med Pregl 2012; 65:388-95

6. Vučević D, Radak Đ, Milovanović I, Radosavljević T, Mladenović D. Patofiziološki mehanizmi angiogeneze u aterogenezi. Med Pregl 2013; 66:297-306.

7. Vučević D, Radosavljević T, Đorđević D, Mladenović D, Vesković M. The relationship between atherosclerosis and pulmonary emphysema. Med Review 2014; 67:231-8.

8. Vučević D, Jorgačević B, Radosavljević T, Radak Đ, Kovačević D. Povezanost insulinske rezistencije i poremećaja kardiovaskularnog sistema. Med Istraž 2015; 49:5-15.

9. Stone NJ. Treatment of blood cholesterol to reduce atherosclerotic cardiovascular disease risk in adults: synopsis of the 2013 American College of Cardiology /American Heart Association Cholesterol Guideline. Ann Intern Med 2014; 160:339-43.
10. Wang X. Cholesterol levels and risk of hemorrhagic stroke: a systematic review and meta-analysis. Stroke 2013; 44:1833-9.

11. Wilkins JT. Coronary heart disease risks associated with high levels of HDL cholesterol. J Am Heart Assoc 2014; 3:e000519.

12. 1Rached FH. An overview of the new frontiers in the treatment of atherogenic dyslipidemias. Clin Pharmacol Ther 2014; 96:57-63.

13. Karalis DG. Intensive-lowering of low-density lipoprotein cholesterol levels for primary prevention of coronary artery disease. Mayo Clin Proc 2009; 84:345-52.

14. Ridker PM. LDL cholesterol: controversies and future therapeutic directions. Lancet 2014; 384:607-17.

15. Manojlović D. Klinička klasifikacija i sindromi hiperlipoproteinemija. U: Manojlović D, urednik. Poremećaji metabolizma lipida. Vršac: INEX Hemofarm DD; 1992. s. 15-30.

16. Pešić BČ, Vučević D. Nasledni poremećaji metabolizma masti. U: Pešić BČ, urednik. Patofiziologija: mehanizmi poremećaja zdravlja - prvi deo. Beograd: Medicinski fakultet Univerziteta u Beogradu; 2015. s. 166-74.

17. Ross R. Atherosclerosis - an inflammatory disease. N Engl J Med 1999; 340:115-26.

18. Rader DJ. HDL and cardiovascular disease. Lancet 2014; 384:618-25

19. Santos RD. What is new in familial hypercholesterolemia? Curr Opin Lipidol 2014; 25:183-8.

20. Novaković I. Genetička osnova vaskularnih poremećaja. U: Maksimović Ž, gl. urednik. Osnove vaskularne hirurgije i angiologije. Beograd: Medicinski fakultet Univerziteta u Beogradu, CIBID; 2004. s. 34-38.

21. Vučević D, Pešić BČ. Stečeni poremećaji metabolizma masti. U: Pešić BČ, urednik. Patofiziologija: mehanizmi poremećaja zdravlja - prvi 
deo. Beograd: Medicinski fakultet Univerziteta u Beogradu; 2015. s. 425-33.

22. Friedman JM. Obesity: Causes and control of excess body fat. Nature 2009; 459:340-2.

23. Berglund L. Evaluation and treatment of hypertriglyceridemia: an Endocrine Society clinical practice guideline. J Clin Endocrinol Metab 2012; 97:2969-89.

24. Nordestgaard BG. Triglycerides and cardiovascular disease. Lancet 2014; 384:626-35

25. Vučević D, Mladenović D, Ninković M, Aleksić V, Stanković MN, Stanković M. The effects of caloric restriction against ethanol-induced oxidative and nitrosative cardiotoxicity and plasma lipids. Exp Biol Med (Maywood) 2013; 1396-1405.

26. Frostegárd J. Immune mechanisms in atherosclerosis, especially in diabetes type 2. Front Endocrinol 2013, 4:162-72.
27. Gaggini M, Morelli M, Buzzigoli E, DeFronzo RA, Bugianesi E, Gastaldelli A. Non-alcoholic fatty liver disease (NAFLD) and its connection with insulin resistance, dyslipidemia, atherosclerosis and coronary heart disease. Nutrients 2013; 5:1544-60.

28. Harris MF. The metabolic syndrome. Aust Fam Physician 2013; 42:524-

29. Krum H, Abraham WT. Heart failure. Lancet 2009; 373:941-55.

30. Iantorno M, Campia U, Di Daniele N, Nisticó S, Forleo GB, Cardillo C. Obesity, inflammation and endothelial dysfunction. J Biol Regul Homeost Agents 2014; 28:169-76.

31. Jackson KG, Poppitt SD, Minihane AM. Postprandial lipemia and cardiovascular disease risk: interrelationships between dietary, physiological and genetic determinants. Atherosclerosis 2012; 220:22-33.

32. Rees K. „Mediterranean“ dietary pattern for the primary prevention of cardiovascular disease. Cochrane Database Syst Rev 2013; 8:CD009825. 